\title{
Studi Komparasi Kepuasan Pasien BPJS Dan Non BPJS Pada Mutu Pelayanan Pendaftaran Puskesmas Johar Baru Jakarta Pusat
}

\author{
Maya Sofiana $^{\mathrm{a}, 1, *}$, Rita Wahyuni ${ }^{\mathrm{b}, 2}$, Endang Supriyadi ${ }^{\mathrm{b}, 3}$ \\ a Institut Ilmu Sosial dan Manajemen STIAMI \\ b Institut Ilmu Sosial dan Manajemen STIAMI \\ ${ }^{1}$ maya72sofiana@gmail.com * \\ * corresponding author
}

\section{ARTICLE INFO}

\section{Article history}

Received

Revised

Accepted

\section{Keywords}

Health BPJS and Non BPJS,

Patient Satisfaction,

Quality of Regisgtration

Services.

\begin{abstract}
The patient registration service is the starting gate for the health center services. In implementing BPJS, the community expects to get satisfactory health services. Patients will feel or not depends on the quality of registration services provided. If the patient feels satisfied the he will come back to get health care. However, if the patient is not satisfied, there will be many complaints that will not only be delivered face-to-face but more than that it can occur the complaint is submitted thorugh print media, visual media, and even social media. The purpose of study was to determine the comparative satisfaction of BPJS and non BPJS patients on the quality of registration services at the Johar Baru Health Center in Central Jakarta.riptive method with a Cross Sectional Comparative approach in the registration section at Johar Baru Health Center, Central Jakarta

Research methods. This research was conducted with a descriptive method with a Cross Sectional Comparative approach in the registration section at Johar Baru Health Center, Central Jakarta. The population in this study were BPJS and Non BPJS patients who registered at the outpatient Registration in October-December 2019. The method of selecting samples was used with probability sampling whie to take samples using the proportionate stratified random sampling technique. The tool used for research with Questionnaire/Questionnaire. With a Likert scale measurement scale. For data analysis techniques using the Vality Test used is the product moment correlation which results in that the whoe question items are valid, which decision considerations are based on the $\mathrm{r}$ table for $\mathrm{N}=30$ at a significance of $5 \%$, amounting to 0.361 . Realibility Tests are used to show the extent to which a measurement result is relatively consistent if our measuring instrument repeatedly. Based on the reliability test, for the item questionnaire, the decision consideration is based on Cronbach'salfa value $>0.60$, the questionnaire is declared reliable or consistent. In this study the Cronvachs's Alfa Value of 0.699 's was rounded to 0.70, the cronbanch Alfa Value of $0.70>0.60$, the questionnaire was declared reliable or consistent. With cross sectional time approach. The Mann Whitney U test was used to prove the hypothesis with the SPSS For Windows 25 software version, the significance value or Symp was obtained. Sig, (2 tailed) of 0.001 . Therefore the value of Symp. Sig, ( 2 tailed) of $0.001>$ from the probability of $0.0 \mathrm{f}$, the hypothesis "Ha is a accepted" or there is a difference. Based on the average value in the level of BPJS patient satisfaction obtained an average of 79.96 for Non BPJS patients obtained an average of 76.13 while the difference between the two amounted to 3.83 .

Targeted Output. Is a scientific publication in the National Journal of ISSN submitted, speakers in scientific meetings are registered, teaching material (ISBN) draft newspapaer articles are published. The proposed TKT research is TKT 1
\end{abstract}

\section{PENDAHULUAN}

Dalam rangka meningkatkan kesehatan masyarakat Indonesia pemerintah menyelenggarakan program kesehatan, yang mulai tanggal tanggal 1 Januari 2014, Indonesia melakukan perubahan dalam sistem pembiayaan kesehatan, seperti tercantum dalam Undang-undang No. 40 Tahun 2004 tentang Sistem Jaminan Kesehatan Nasional (SJSN), yang mana seluruh rakyat Indonesia secara bertahap mulai tahun 2014 
sampai dengan 2019 akan ditanggung biaya kesehatannya. Adapun penyelenggara jaminan kesehatan nasional ini diatur dalam UU No. 24 Tahun 2011 tentang BadaDalamn Penyelenggara Jaminan Sosial (BPJS). BPJS merupakan badan usaha milik Negara yang ditugaskan khusus oleh pemerintah untuk rakyat Indonesia, terutama untuk pegawai negeri sipil, penerima pensiun PNS dan TNI/POLRI, veteran, perintis kemerdekaan beserta kelarganya dan Badan Usaha lainnya ataupun rakyat biasa.

Pemerintah melalui Puskesmas, Posyandu, dan Rumah Sakit memberikan pelayanan kesehatan. Menurut Departemen Kesehatan RI dalam Keputusan Menteri Kesehatan (Kepmenkes) RI No. 128 Menkes/SK/II/2004, puskesmas merupakan unit pelaksana teknis Dinas Kesehatan kabupaten/kota yang bertanggung jawab menyelenggarakan pembangunan kesehatan di wilayah kerja. Puskesmas juga merupakan salah satu sarana pelayanan publik yang secara langsung dapat dirasakan masyarakat pengguna, khususnya dalam pelayanan kesehatan perorangan. Cakupan pelayanan yang diterima masyarakat selaku pra sejahtera peserta BPJS Kesehatan di FKTP (Fasilitas Kesehatan Tingkat Pertama) atau puskesmas yaitu rawat jalan tingkat pertama, pelayanan gigi, rawat inap tingkat pertama dan pelayanan darah sesuai indikasi medis.

Dalam peraturan Menteri Pendayagunaan Aparatur Negara dan Reformasi Birokrasi, No. 15 Tahun 2014, Tentang Pedoman Standar Pelayanan, Standar Pelayanan prima adalah tolak ukur yang dipergunakan sebebagai pedoman penyelenggaraan pelayanan dan acuan penilaian kualitas pelayanan sebagai kewajiban dan janji penyelengara kepada masyarakat dalam rangka pelayanan yang berkualitas, cepat, mudah, terjangkau, dan terukur.

Undang-Undang (UU) nomor 36 tahun 2009 tentang kesehatan menekankan pentingnya upaya peningkatan mutu pelayanan kesehatan. Mutu pelayanan kesehatan di sini merupakan tingkat kesempurnaan pelayanan kesehatan yang diselenggarakan oleh penyedia jasa layanan kesehatan kepada penerima jasa layanan kesehatan yang mana penerima jasa kesehatan menerima pelayanan yang memuaskan dan pemberi jasa layanan kesehatan memberikan pelayanan sesuai dengan kode etik dan standar. Mutu pelayanan yang baik saat ini menjadi penting untuk meningkatkan kualitas pelayanan dan kepuasan pasien. Setiap pasien selalu mengharapkan pelayanan yang berkualitas sehingga dapat tercapai kepuasan. Oleh karenanya setiap unit pelayanan kesehatan harus memberikan pelayanan yang sama kepada setiap pasien baik sebagai pasien BPJS PBI maupun non PBI. Pasien akan membandingkan layanan yang diterima dengan apa yang diharapkan. Namun bila pasien tidak merasa puas maka akan terjadi banyak keluhan yang bahkan tidak hanya akan disampaikan secara tetap muka namun lebih dari itu dapat terjadi bahwa keluhan tersebut disampaikan melalui media cetak, media visual, bahkan sosial media. Sehingga indikator mutu pelayanan kesehatan dapat dilihat dari kepuasan pasien, Terkait dengan hal tersebut puskesmas dapat meningkatkan mutu berdasarkan kepuasan pasien. Tingkat kepuasan pasien harus diukur dengan secara akurat, berkala, teratur dan berkesinambungan

Pelayanan pendaftaran pasien merupakan pintu gerbang dimulainya pelayanan puskesmas. Dalam penyelenggaraan kesehatan, masyarakat mengharapkan mendapatkan pelayanan kesehatan yang memuaskan. Pasien akan akan merasa puas atau tidak, tergantung dari mutu pelayanan pendaftaran yang diberikan tanpa membedakan pasien BPJS dan Non BPJS. Apabila pasien merasa puas maka akan datang kembali untuk mendapatkan pelayanan kesehatan.

Puskesmas dalam pemberian pelayanan kesehatan, maka kesan pertama yang dilihat dan dirasakan pasien terhadap kualitas layanan kesehatan adalah kualitas pelayanan pendaftaran pasien rawat jalan dan kesan yang ditampilkan petugas pendaftaran kepada pasien. Permasalahan umum yang terjadi dalam dalam hal ini adalah masih banyak masyarakat yang belum memahami mekanisme pelayanan dalam programnya. Pandangan pasien terhadap BPJS masih kurang baik, misal seperti menunggu dalam waktu yang tidak wajar, prosedur pelayanan yang rumit, kegagalan dalam komunikasi, krisis waktu, sikap petugas pendaftaran yang tidak sabar, tidak tanggap dan tidak ramah, serta petugas kesehatan yang kurang memperhatikan keluhan pasien dan keluarganya. Berdasarkan pengamatan penulis sudah cukup baik dan harus dipertahankan namun masih terlihat antrian panjang dan parkir yang sangat padat.

Pasien BPJS dan Non BPJS yang mendapatkan pelayanan di Puskesmas perlu diperhatikan apakah terjadi kesenjangan antara pelayanan antara pasien BPJS dan pasien non BPJSs, karena dalam Undangundang No. 36 Tahun 2009 tentang Kesehatan pada Pasal 4 disebutkan bahwa setiap orang mempunyai hak yang sama akses atas sumber daya di bidang kesehatan. 
Puskesmas Johar Baru merupakan Fasilitas Kesehatan Tingkat Pertama (FKTP), sebagai salah satu pemberi pelayanan kesehatan maka Puskesmas Johar Baru harus berorientasi memberikan pelayanan yang memuaskan bagi pasien. Berdasarkan hasil observasi pendahuluan dan wawancara yang dilakukan pada 5 Desember diperoleh data Puskesmas Johar Baru ditunjang oleh Dokter Umum 8 orang, Dokter Gigi 5 orang, Apoteker 1 orang, Asisten Apoteker 1 orang, Perawat 13 orang, Perawat Gigi 1 orang, Bidan 3 orang, Sanitarian 1 orang, Pranata Laboratorium1 orang, Nutrisionis 3 orang, Admin Loket 1 orang, Tahun 2018 jumlah kunjungan rawat jalan di Puskesmas Johar Baru adalah yang tertinggi yaitu sebanyak 160.362 jiwa terdiri dari 89.411 jiwa berjenis kelamin perempuan dan 70.951 jiwa berjenis kelamin laki-laki.

Pelayanan kesehatan pada Puskesmas Johar Baru sendiri perlu diperhatikan apakah selama ini pelayanan yang diberikan kepada pasien menimbulkan ketidakpuasan dan berpengaruh terhadap mutu pelayanan. Oleh karena itu, puskesmas harus berorientasi pada kepuasan pasien tanpa membedakan status pasien BPJS atau Non BPJS, dengan meningkatkan mutu pelayanan berupa standar keahlian (profesi) untuk memenuhi kebutuhan dan keinginan pasien sehingga pasien dapat memperoleh kepuasan sehingga pada gilirannya dapat meningkatkan kepercayaan pada pihak pemberi layanan melalui pelayanan yang prima.

Berdasarkan latar belakang tersebut maka peneliti tertarik untuk mengambil judul Studi Komparasi Kepuasan Pasien BPJS dan Non BPJS pada Mutu Pelayanan Pendaftaran Rawat Jalan Puskesmas Johar Baru Jakarta Pusat.

\section{Konsep BadanPenyelenggara Jaminan Sosial (BPJS)}

\section{BPJS}

BPJS merupakan program yang baru di Indonesia dalam rangka meningkatkan kualitas kesehatan rakyatnya. Adapun definisi BPJS adalah badan hukum yang dibentuk dengan UU BPJS untuk menyelenggarakan program jaminan sosial. Undang-undang Nomor 24 Tahun 2011 tentang Badan Penyelenggara Jaminan Sosial (BPJS). Pasal 60 ayat 1 UU BPJS menyatakan bahwa BPJS Kesehatan mulai beroperasi tanggal 7 Januari 2014.

Dalam Undang-Undang Nomor 24 Tahun 2011 juga dijelaskan bahwa badan penyelenggara jaminan sosial kesehatan atau disebut dengan BPJS kesehatan merupakan badan hukum yang dibentuk untuk menyelenggarakan program jaminan sosial dan menyelenggarakan jaminan pemeliharaan kesehatan bagi seluruh rakyat Indonesia.

\section{Kepesertaan BPJS Kesehatan PBI dan Non PBI}

Dalam rangka meningkatkan pelayanan kesehatan maka kepesertaan BPJS diklasifikasikan menjadi 2 golongan. Menurut Herlambang (2016) Peserta BPJS Kesehatan adalah setiap orang, termasuk orang asing yang bekerja paling singkat 6 (enam) bulan di Indonesia, yang telah membayar iuran.

\section{Iuran BPJS}

Untuk keberlangsungan pelaksanakan program BPJS yang bersifat nasional, maka peserta BPJS dikenakan iuran. Untuk iuran BPJS diklasifikasikan menjadi beberapa golongan. Menurut Herlambang (2016), Ketentuan iuran peserta BPJS, adalah sebagai berikut:

a. Bagi peserta Penerima Bantuan Iuran (PBI) Jaminan Kesehatan iuran dibayar oleh Pemerintah.

b. Iuran bagi Peserta Pekerja Penerima Upah yang bekerja pada Lembaga Pemerintahan membayar sebesar 5\% (lima persen) dari Gaji atau Upah pe kerja dan 2\% (dua persen) dibayar oleh peserta.

c. Iuran bagi Peserta Pekerja Penerima Upah yang bekerja di BUMN, BUMD dan Swasta sebesar 4,5\% (empat koma lima persen) dari Gaji atau Upah per bulan dengan ketentuan: 4\% (empat persen) dibayar oleh Pemberi Kerja dan 0,5\% (nol koma lima persen) dibayar oleh peserta.

d. Iuran untuk keluarga tambahan pekerja Penerima Upah yang terdiri dari anak ke 4 dan seterusnya, ayah, ibu dan mertua, besaran iuran sebesar $1 \%$ (satu persen) dari gaji atau upah per orang per bulan, dibayar oleh pekerja penerima upah.

e. Iuran bagi kerabat lain dari pekerja penerima upah (seperti saudara kandung/ipar, asisten rumah tangga, dan lain-lain); peserta pekerja bukan penerima upah serta iuran peserta bukan pekerja adalah 
sebesar: a. Sebesar Rp.25.500,- (dua puluh lima ribu lima ratus rupiah) per orang per bulan dengan manfaat pelayanan diruang perawatan Kelas III. b. Sebenarnya Rp.59.500,- (lima puluh Sembilan ribu lima ratus rupiah) per orang per bulan dengan manfaat pelayanan diruang perawatan Kelas II. c. Sebesar Rp.80.000,- (delapan puluh ribu rupiah) per orang per bulan dengan manfaat pelayanan diruang perawatan Kelas I.

f. Iuran Jaminan Kesehatan bagi veteran, perintis kemerdekaan, dan janda, duda, atau anak yatim piatu dari veteran atau perintis kemerdekaan, iurannya ditetapkan sebesar 5\% (lima persen) dari 45\% (empat puluh lima persen) gaji pokok pegawai negeri sipil golongan ruang III/a dengan masa kerja 14 (empat belas) tahun per bulan dibayar oleh Pemerintah. 7. Pembayaran iuran paling lambat tanggal 10 (sepuluh) setiap bulan.

\section{Konsep Kepuasan Pasien}

\section{Kepuasan Pasien}

Kepuasan pelanggan akan timbul apabila harapan pelanggan terlampaui. Yang mana kepuasan itu sendiri merupakan rasa senang atau kecewa yang dihasilkan dengan membandingkan antara produk atau jasa dengan kinerja. Jika kinerja memenuhi harapan maka pelanggan akan puas dan sebaliknya seperti pendapat Engel (dalam Tjiptono 2016:151) mengungkapkan bahwa kepuasan pelanggan merupakan evaluasi purna beli yang mana alternatif yang dipilih sekurang-kurangnya memberikan hasil (outcome) sama atau melampaui harapan pelanggan, sedangkan ketidakpuasan timbul apabila hasil yang diperoleh tidak memenuhi harapan pelanggan. Sementara itu Kotler \& Keller (2016:153) berpendapat

Satisfaction is a person's feelings of pleasure or disappointment that result from comparing a productor service's perceived performance (or outcome) to expectations. If the performance or experience falls short of expectations, the customer is dissatisfied. If it matches expectations, the customer is satisfied. If it exceeds expectations, the customer is highly satisfied or delighted.

(Kepuasan adalah perasaan seseorang kesenangan atau kekecewaan yang dihasilkan dari membandingkan pelayanan produk yang dirasakan kinerja (atau hasil) dengan yang di harapakan. Jika kinerja, atau pengalaman jatuh jauh dari harapan, pelanggan puas. Jika itu sesuai harapan, pelanggan puas. Jika memang melebihi harapan, pelanggan sangat puas atau senang).

Kepuasan pasien menurut Rahmayanty (2013) adalah evaluasi positif dari dimensi pelayanan yang beragam. Pelayanan yang dievaluasi dapat berupa sebagian kecil dari pelayanan dan semua jenis pelayanan kesehatan.

Seperti diketahui dari pernyataan di atas bahwa, kepuasan dihasilkan dengan membandingkan kinerja dengan harapan pelanggan. Ketidakpuasan akan terjadi karena adanya kesenjangan antara kinerja dengan harapan pelanggan yang menyebabkan perbedaan persepsi. Hal ini terlihat dari pendapat Lupiyoadi, (2013:219) ada lima kesenjangan (gap) yang menyebabkan adanya perbedaan presepsi mengenai kualitas jasa adalah sebagai berikut:
a. Kesenjangan Presepsi Manajemen
b. Kesenjangan Spesifikasi Kualitas
c. Kesenjangan Penyampaian Jasa
d. Kesenjangan Komunikasi Pemasaran
e. Kesenjangan Dalam Pelayanan yang Dirasakan

Pencapaian kepuasan akan terjadi seperti pendapat Kotler dalam Lupiyoadi (2001:158) meninjau lebih lanjut, pencapaian kepuasan pelanggan melalui kualitas pelayanan, dapat ditingkatkan dengan beberapa pendekatan sebagai berikut:

1) Memperkecil kesenjangan-kesenjangan yang terjadi antara pihak manajemen dan pelanggan.

2) Perusahaan harus mampu membangun komitmen bersama untuk menciptakan visi di dalam perbaikan proses pelayanan.

3) Memberikan kesempatan kepada pelanggan untuk menyampaikan keluhan.

4) Mengembangkan dan menerapkan accountable, proactive, dan partnership marketing sesuai dengan situasi pemasaran. 


\section{Pengukuran Kepuasan}

Untuk meningkatkan upaya mutu pelayanan penting sekali dilakukan pengukuran kepuasan. Dalam hal ini Tjiptono (2012:318) mengemukakan terdapat empat metode untuk mengukur kepuasan pelanggan yaitu:
a. Sistem Keluhan dan Saran
b. Survei Kepuasan Pelanggan
c. Ghost Shopping
d. Lost Customer Analysis

Kepuasan pasien dapat dilihat dari hak-hak yang dimiliki pasien yang sebagai peserta dapat terpenuhi. Menurut UU No.36 tahun 2009 tentang kesehatan, pada pasal 4-8 disebutkan setiap orang berhak atas kesehatan, memperoleh akses atas sumber daya di bidang kesehatan, memperoleh pelayanan kesehatan yang aman, bermutu dan terjangkau; menentukan sendiri pelayanan kesehatan yang diperlukan bagi dirinya, lingkungan yang sehat, info dan edukasi kesehatan yang seimbang dan bertanggungjawab, dan informasi tentang data kesehatan dirinya termasuk tindakan dan pengobatan yang telah maupun yang akan diterimanya dari tenaga kesehatan.

Hak-hak pasien dalam UU No. 36 tahun 2009 itu diantaranya meliputi:

1) Hak menerima atau menolak sebagian atau seluruh pertolongan (kecuali tak sadar, penyakit menular berat, gangguan jiwa berat).

2) Hak atas rahasia pribadi (kecuali perintah UU, pengadilan, ijin yang bersangkutan, kepentingan yang bersangkutan, kepentingan masyarakat).

3) Hak tuntut ganti rugi akibat salah atau kelalaian (kecuali tindakan penyelamatan nyawa atau cegah cacat).

\section{Konsep Mutu/Kualitas Pelayanan}

\section{Pelayanan}

Manusia dalam memenuhi kebutuhannya memerlukan proses melalui pihak lain, seperti definisi Pelayanan, menurut Moenir dalam Pasolong (2010:2018), proses pemenuhan kebutuhan melalui aktifitas orang lain secara langsung.

Kebutuhan manusia akan selalu berkembang oleh karena itu pelayanan yang diberikan harus mengikuti agar dapat melampai harapan dalam hal ini pelanggan atau pengguna jasa. Rahmayanty (2010:17) berpendapat Pelayanan prima adalah "pelayanan yang sangat baik dan melampaui harapan pelanggan,pelayanan dengan standar kualitas yang tinggi dan selalu mengikuti perkembangan kebutuhan pelanggan setiap saat, secara konsisten dan akurat (handal)".

Pengertian lain menurut Daryanto dan Setyabudi (2014:107) bahwa proses pelayanan prima adalah "rangkaian kegiatan atau aktivitas memberikan pelayanan optimal kepada pelanggan". menumbuhkan dan menciptakan prosesnya dapat terbentuk, yaitu dengan tujuan dan fungsinya.

\section{Pelayanan Publik}

Pemerintah memberikan pelayanan publik kepada masyarakat untuk memenuhi kebutuhannya, dan kebutuhan tidak dapat dipisahkan dari kehidupan manusia serta diberikan sesuai dengan aturan yang telah ditetapkan. Dalam keputusan MENPAN Nomor 63 Tahun 2003 dirumuskan bahwa pelayanan publik sebagai upaya pemenuhan kebutuhan penerima pelayanan maupaun pelaksana ketentuan perundangundangan. Pendapat yang dikemukakan Sinambella, dkk, (2006:3) "pada dasarnya setiap manusia membutuhkan pelayanan, bahkan secara ekstrim dapat dikatakan bahwa pelayanan tidak dapat dipisahkan dengan kehidupan manusia.

Pelayanan publik menurut Kurniawan (2005:4) bahwa "pelayanan publik adalah melayani keperluan orang lain atau masyarakat yang mempunyai kepentingan pada organisasi itu sesuai dengan aturan pokok dan tata cara yang telah ditetapkan. 


\section{Prinsip Pelayanan Publik}

Agar pelaksanaan pelayanan publik tersebut lebih optimal, harus memenuhi ketentuan prinsip pelayanan publik. Mahmudi (2010:228-229) berpendapat prinsip-prinsip pelayanan prima adalah sebagai berikut:
a. kesederhanaan prosedur,
b. kejelasan,
c. kepastian waktu,
d. akurasi produk pelayanan publik,
e. kelengkapan sarana dan prasarana,
f. keamanan,
g. tanggungjawab,
h. kemudahan akses,
i. kedisiplinan,
j. kenyamanan

\section{Jenis Pelayanan Publik}

Masyarakat dalam memenuhi kebutuhan dijamin pelayanan publiknya oleh pemerintah dalam bentuk pelayanan administrative, pelayanan barang dan pelayanan jasa. Seperti pendapat Hardiyansyah (2011:23) jenis pelayanan umum atau publik yang diberikan pemerintah terbagi dalam tiga kelompok, yaitu:
a. Pelayanan administratif Pelayanan administratif
b. Pelayanan Barang Pelayanan barang
c. Pelayanan Jasa Pelayanan jasa

\section{Pelayanan Kesehatan}

Kesehatan merupakan kebutuhan dasar dan hak masyarakat. Pelayanan kesehatan merupakan salah satu hak mendasar masyarakat yang penyediaannya wajib diselenggarakan oleh pemerintah sebagaimana telah diamanatkan dalam Undang-undang Dasar 1945 pasal 28 H ayat (1) yaitu:

"Setiap orang berhak hidup sejahtera lahir dan batin, bertempat tinggal, dan mendapatkan lingkungan hidup yang baik dan sehat serta berhak memperoleh pelayanan kesehatan" dan Pasal 34 ayat (3) "Negara bertanggung jawab atas penyediaan fasilitas pelayanan kesehatan dan fasilitas pelayanan umum yang layak".

Dalam hal ini pelayanan kesehatan sebagai organisasi melakukan penanganan kesehatan kepada masyarakat baik secara sendiri atau bersama-sama. Mubarak dan Nurul Chayatin, (2009: 132) berpendapat Pelayanan Kesehatan adalah suatu organisasi untuk memelihara dan meningkatkan kesehatan, mencegah dan menyembuhkan penyakit, serta memulihkan kesehatan perseorangan, keluarga, kelompok, dan masyarakat.

Menurut Lovely dan Loomba dalam Muriany ( 2016: 40) pelayanan kesehatan adalah setiap upaya yang diselenggarakan secara sendiri atau bersama-sama dalam suatu organisasi untuk memelihara, meningkatkan kesehatan, mencegah dan menyembuhkan penyakit serta memulihkan kesehatan perorangan, keluarga, kelompok dan ataupun, masyarakat.

Bagian Pendaftaran merupakan salah satu bagian dari jajaran Administrasi dan menajemen dalam pelayanan Kesehatan. Menurut Herlambang (2012) dan Alamsyah (2011) jenis pelayanan kesehatan yang ada di Rumah Sakit secara umum yaitu : Administrasi dan Manajemen yang mana jajaran administrasi dan manajemen sering disebut dengan jajaran struktural tugasnya adalah pelayanan dibidang administrasi, yang termasuk dalam pelayanan ini adalah bagian pendaftaran, dan kasir. Pelayanan yang dinilai adalah sikap, tanggap dan kepastian dari para petugas.

Dalam upaya meningkatkan mutu layanan, pemberi layanan harus memahami masyarakat yang dilayani seperti menurut Pohan (2006:14) pemberi layanan kesehatan harus memahami status kesehatan dan kebutuhan layanan kesehatan masyarakat yang dilayaninya. Agar terealisir hal tersebut pemerintah mengatur dalam Peraturan Menteri Kesehatan Nomor 71 Tahun 2013 tentang pelayanan kesehatan pada JKN (Jaminan Kesehatan Nasional) mendefinisikan penyelenggara pelayanan kesehatan meliputi 
semua fasilitas kesehatan yang bekerja sama dengan BPJS (Badan Penyelenggara Jaminan Sosial) Kesehatan berupa fasilitas kesehatan tingkat pertama dan fasilitas kesehatan rujukan tingkat lanjutan dan mendidik masyarakat tentang layanan kesehatan dasar dan melibatkan masyarakat dalam menentukan bagaimana cara efektif menyelenggarakan layanan kesehatan.

\section{Mutu/Kualitas Pelayanan}

Untuk memenuhi keinginan dan kebutuhan pasien maka layanan yang diberikan harus sesuai dengan prosedur medis dan dipraktikkan dengan cara dan gaya yang pada setiap kondisi. Menurut Margaretha (2003: 75), mutu didefinisikan sebagai suatu konsep yang diterapkan dan dipraktikkan dengan cara dan gaya yang sama pada setiap keadaannya. Mutu adalah sejauh mana layanan kesehatan yang diberikan sesuai dengan standard operating procedure atau prosedur tetap medis Mukti, (2007:9).

Dalam memenuhi kebutuhan pelanggan bahwa pelayanan yang diberikan tidak hanya memenuhi harapan pelanggan tetapi berada di tingkat keunggulan. Zeitmal dan Bitner dalam Madubun (2017:73) kualitas pelayanan adalah tingkat keunggulan yang diharapkan dan pengendalian atas tingkat keunggulan tersebut untuk memenuhi keinginan pelanggan.

Pelayanan kesehatan diberikan kepada masyarakat harus sesuai dengan kode etik dan standar pelayanan profesi yang ditetapkan. Marjati, dkk, (2014:1) berpendapat Mutu pelayanan kesehatan adalah timbulnya kepuasan pada setiap pasien sesuai dengan tingkat kepuasan rata-rata penduduk, serta tata cara penyelenggaraan sesuai dengan kode etik dan standar pelayanan profesi yang ditetapkan.

Pelayanan kesehatan merupakan usaha yang diberikan kepada pasien untuk memenuhi kebutuhan kesehatan dan harus dapat memuaskan pasien. Oleh karena itu tujuan pelayanan kesehatan dalam Permenkes RI Nomor 75 Tahun 2014:

a. Promotif

1) Preventif Preventif primer

2) Preventif sekunder Preventif tersier

b. Kuratif

c. Rehabilitasi

Demikian pula dalam hal ini Puskesmas Johar Baru, Secara garis besar kegiatan Puskesmas meliputi :
a. Kegiatan Promotif
b. Kegiatan Preventif
c. Kegiatan Kuratif
d. Kegiatan Rehabilitatif

Berdasarkan tempat kegiatan Puskesmas terbagi atas :

a. Kegiatan di dalam gedung

b. Kegiatan di luar gedung

Puskesmas bertanggung jawab menyelenggarakan upaya kesehatan perorangan dan masyarakat. Upaya kesehatan tersebut terbagi menjadi dua, yaitu :

a. Upaya Kesehatan Essensial

1) Upaya Promosi Kesehatan

2) Upaya Kesehatan Lingkungan

3) Upaya Kesehatan Ibu dan Anak serta KB

4) Upaya Perbaikan Gizi Masyarakat

5) Upaya Pencegahan dan Pemberantasan Penyakit Menular

6) Perawatan Kesehatan Masyarakat

b. Upaya Kesehatan Pengembangan

1) Upaya Kesehatan Sekolah (UKS) dan Upaya Kesehatan Gigi Sekolah (UKGS)

2) Pelayanan Kesehatan Lansia

3) Pelayanan Kesehatan Jiwa

4) Ketuk Pintu Layani Dengan Hati (KPLDH)

5) Layanan Warung Sehat

6) Prolanis Senam Ibu Hamil 


\section{Standar Pelayanan}

Upaya pencapaian mutu pelayanan harus dibakukan dalam sebuah pedoman standar pelayanan. Dalam peraturan Menteri Pendayagunaan Aparatur Negara dan Reformasi Birokrasi, No. 15 Tahun 2014, Tentang Pedoman Standar Pelayanan, Standar Pelayanan prima adalah tolak ukur yang dipergunakan sebebagai pedoman penyelenggaraan pelayanan dan acuan penilaian kualitas pelayanan sebagai kewajiban dan janji penyelengara kepada masyarakat dalam rangka pelayanan yang berkualitas, cepat, mudah, terjangkau, dan terukur. Prinsip penyusunan, penetapan, dan penerapan Standar Pelayanan dilakukan dengan memperhatikan prinsip:
a. Sederhana.
b. Partisipatif.
c. Akuntabel.
d. Berkelanjutan.
e. Transparansi.
f. Keadilan.

Komponen Standar Pelayanan yang diatur dalam Undang-undang Nomor 25 Tahun 2009, dalam peraturan ini dibedakan menjadi dua bagian yaitu:

a. Komponen Standar Pelayanan yang terkait dengan proses penyampaian pelayanan (service delivery)

b. Komponen Standar Pelayanan yang terkait dengan proses pengelolaan pelayanan di internal organisasi (manufacturing)

Konsep dimensi kualitas pelayanan yang paling popular adalah konsep Service Quality (SERVQUAL). SERVQUAL Bustami (2011:5-6) yang terdiri dari lima dimensi pokok, lima dimensi mutu pelayanan diantaranya yaitu:
a. Tangible (bukti langsung
b. Reliability (kehandalan
c. Responsiveness (daya tanggapAssurance (jaminan
d. Empathy (empati)

\section{Konsep Puskesmas}

\section{Puskesmas}

Dalam melaksanakan programnya BPJS Kesehatan bekerja sama dengan salah satunya layanan kesehatan masyarakat yakni puskesmas. Sesuai dengan Permenkes RI Nomor 75 Tahun 2014 Tentang Pusat Kesehatan Masyarakat Pusat Kesehatan Masyarakat yang selanjutnya disebut Puskesmas.

Puskesmas adalah fasilitas pelayanan kesehatan yang menyelenggarakan upaya kesehatan masyarakat dan upaya kesehatan perseorangan tingkat pertama, dengan lebih mengutamakan upaya promotif dan preventif, untuk mencapai derajat kesehatan masyarakat yang setinggi-tingginya di wilayah kerjanya.

Menurut Azwar (2010:125) puskesmas adalah suatu unit pelaksana fungsional yang berfungsi sebagai pusat pembangunan kesehatan, pusat pembinaan peran serta masyarakat dalam bidang kesehatan serta pusat pelayanan kesehatan tingkat pertama yang menyelenggarakan kegiatannya secara menyeluruuh, terpadu dan berkesinambungan pada suatu masyarakat yang bertempat tinggal dalam suatu wilayah tertentu

Puskesmas merupakan layanan kesehatan tingkat pertama yang sangat penting dalam memberikan pelayanan kesehatan kepada masyarakat. Pusksemas sebagai Fasilitas Kesehatan Tingkat Pertama (FKTP) diharapkan dapat memperbaiki dan meningkatkan pelayanan kesehatan kepada masyarakat.

Syarat pendirian Puskesmas berdasarkan Peraturan Menteri Kesehatan Republik Indonesia Nomor 75 Tahun 2014 pasal 10 ayat 1 dan 2:
a. geografis;
b. aksesibilitas untuk jalur transportasi;
c. kontur tanah;
d. fasilitas parkir;
e. fasilitas keamanan; 
f. ketersediaan utilitas publik;

g. pengelolaan kesehatan lingkungan; dan

h. kondisi lainnya.

Untuk meningkatkan mutu pelayanan puskesmas, pemerintah melakukan akreditasi. Akreditasi puskesmas adalah pengakuan yang diberikan oleh lembaga independen penyelenggara akreditasi yang ditetapkan oleh menteri setelah memenuhi standar akreditasi (Permenkes RI No. 46 Tahun 2015). Penetapan status Akreditasi Puskesmas terdiri atas lima tingkatan yaitu :

a. tidak terakreditasi,

b. terakreditasi dasar,

c. terakreditasi madya,

d. terakreditasi utama dan

e. terakreditasi paripurna.

Tujuan diberlakukannya akreditasi puskesmas adalah untuk meningkatkan mutu pelayanan kesehatan pada puskesmas, sehingga dari mutu pelayanan kesehatan yang ditingkatkan dapat memberikan kepuasan bagi pasien atau masyarakat yang menerima pelayanan kesehatan tersebut. Demikian pula Puskesmas Johar Baru saat ini sudah terakreditasi Paripurna.

Puskesmas Kecamatan Johar Baru mempunyai 5 Puskesmas Kelurahan yang bertanggung jawab untuk 4 kelurahan di Kecamatan Johar Baru yaitu :

1. Puskesmas Kelurahan Johar Baru II

2. Puskesmas Kelurahan Johar Baru III

3. Puskesmas Kelurahan Tanah Tinggi

4. Puskesmas Kelurahan Galur

5. Puskesmas Kelurahan Kampung Rawa

Berikut ini rincian ruangan-ruangan per lantai gedung Puskesmas Kecamatan Johar Baru.

Tabel 1

Ruangan Per Lantai Gedung Puskesmas Kecamatan Johar Baru

\begin{tabular}{|c|l|c|}
\hline LANTAI & \multicolumn{1}{|c|}{ PENGGUNAAN } & LUAS (m2) \\
\hline Lantai 1 & $\begin{array}{l}\text { Loket Pendaftaran, Farmasi/Apotik, Ruang Tindakan, Layanan } \\
\text { 24 Jam, Ruang Sarana(Server), Ruang TB Paru/Kusta, Kamar } \\
\text { Jenazah, TPS- Sampah Infeksikus, Toilet Pengunjung, Toilet } \\
\text { Karyawan. }\end{array}$ & 483 \\
\hline Lantai 2 & $\begin{array}{l}\text { Ruang Bersalin, Ruang Perawatan Nifas, Ruang } \\
\text { Perawatan Bayi, Toliet Karyawan, Toilet } \\
\text { Pengunjung. }\end{array}$ & 483 \\
\hline Lantai 3 & $\begin{array}{l}\text { Ruang Pemeriksaan Umum, Loket BPJS, Kasir, Ruang MTBS, } \\
\text { Ruang Lavender, Ruang Konseling, Ruang Pemeriksaan Lansia, } \\
\text { Ruang Pemeriksaan Refraksi, Toilet Karyawan, Toilet } \\
\text { Pengunjung, Gudang Obat, Gudang Alat Kesehatan, Gudang } \\
\text { Vaksin. }\end{array}$ & 483 \\
\hline Lantai 4 & $\begin{array}{l}\text { Laboratorium, Ruang Pemeriksaan Gigi dan Mulut, } \\
\text { Ruang KB, Ruang Nifas, Ruang KIA, Ruang Laktasi, Ruang } \\
\text { Imunisasi, Ruang Gizi, Toilet Karyawan, } \\
\text { Toilet Pengunjung. }\end{array}$ & 483 \\
\hline Lantai 5 & $\begin{array}{l}\text { Ruang Rapat, Ruang Kelas Ibu, Warung Sehat, Ruang Promosi } \\
\text { Kesehatan, Ruang KPLDH, Ruang Kesling, Ruang Pengadaan, } \\
\text { Ruang Perencanaan, Toilet }\end{array}$ & 483 \\
\hline Lantai 6 & $\begin{array}{l}\text { Musholla, Ruang Aula, Ruang Kepala Puskesmas, } \\
\text { Ruang Kepala Tata Usaha, Ruang Keuangan, Ruang } \\
\text { Kepegawaian, Ruang Pengadaan Barang,Toilet }\end{array}$ & 483 \\
\hline
\end{tabular}

Sumber : Puskesmas Kecamatan Johar Baru 


\section{Pendaftaran Rawat Jalan}

\section{a. Pendaftaran}

Registrasi/Pendaftaran adalah proses pendaftaran Puskesmas yang meliputi pengajuan dan pemberian kode Puskesmas (Permenkes No.75 Tahun 2014). Secara umum data yang akan dikumpulkan di pos pendaftaran dapat dibagi atas komponen identitas dan pendaftaran, dimana komponen identitas akan mencatat data penting mengenai identitas pasien. Dalam hal ini data penting mengenai nama, alamat, jenis kelamin, usia, pekerjaan dan penanggung jawab atas pembayaran pelayanan ini harus dikumpulkan.

\section{b. Rawat Jalan}

Rawat jalan adalah pelayanan keperawatan kesehatan perorangan yang meliputi observasi, diagnosis, pengobatan, rehabilitasi medik tanpa tinggal di ruang rawat inap pada sarana kesehatan puskesmas, cakupan rawat jalan adalah jumlah kunjungan kasus baru rawat jalan di sarana kesehatan puskesmas dalam kurun waktu satu tahun Al-Assaf AF (2009:355). Adapun prosedur pelayanan rawat Jalan di Puskesmas Johar Baru, adalah sebagai berikut:

Gambar 1

Prosedur Pelayanan Rawat Jalan di Puskesmas Johar Baru

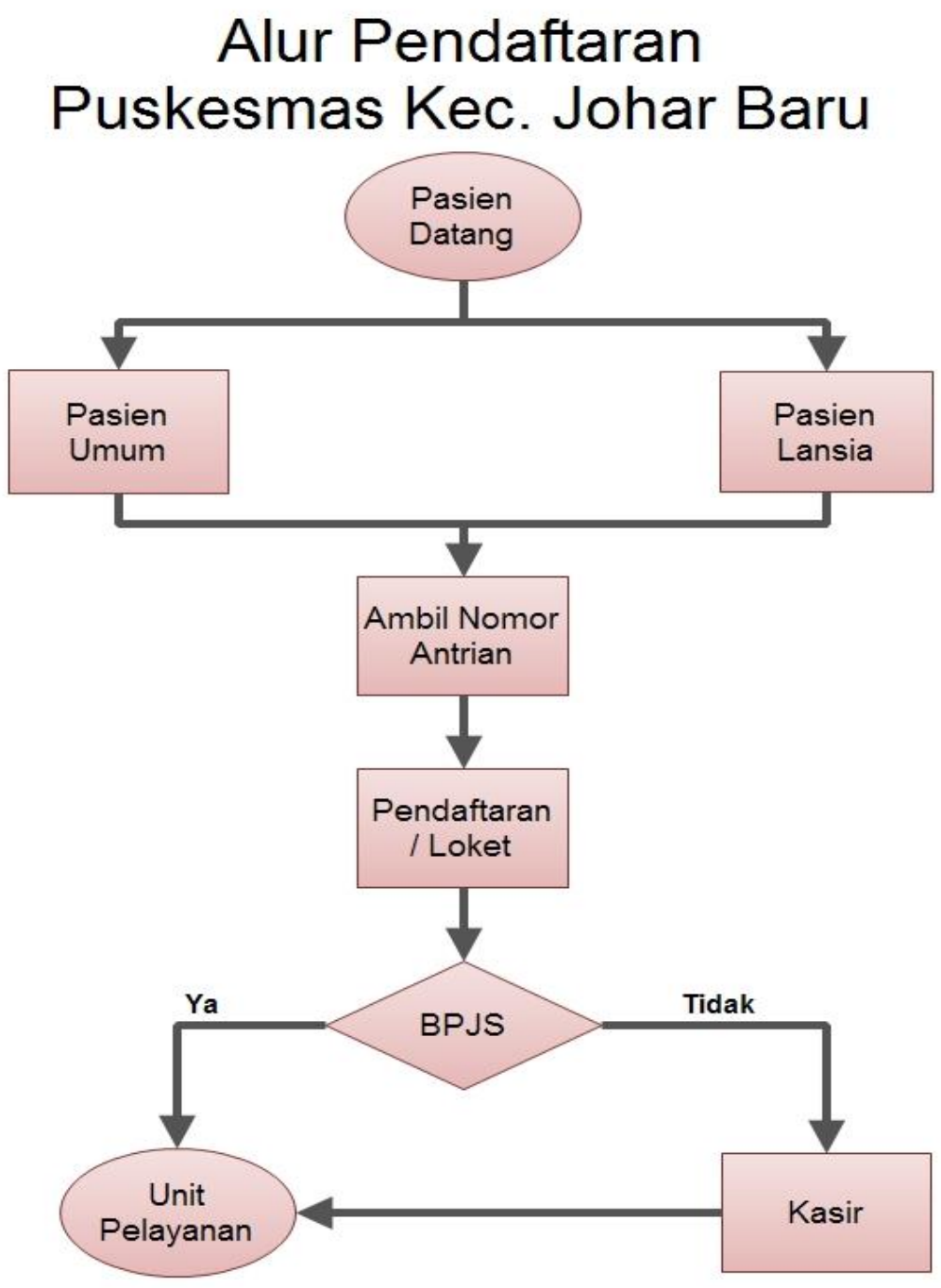

Sedangkan Prosedur Pelayanan Gawat Darurat sebagai berikut: 


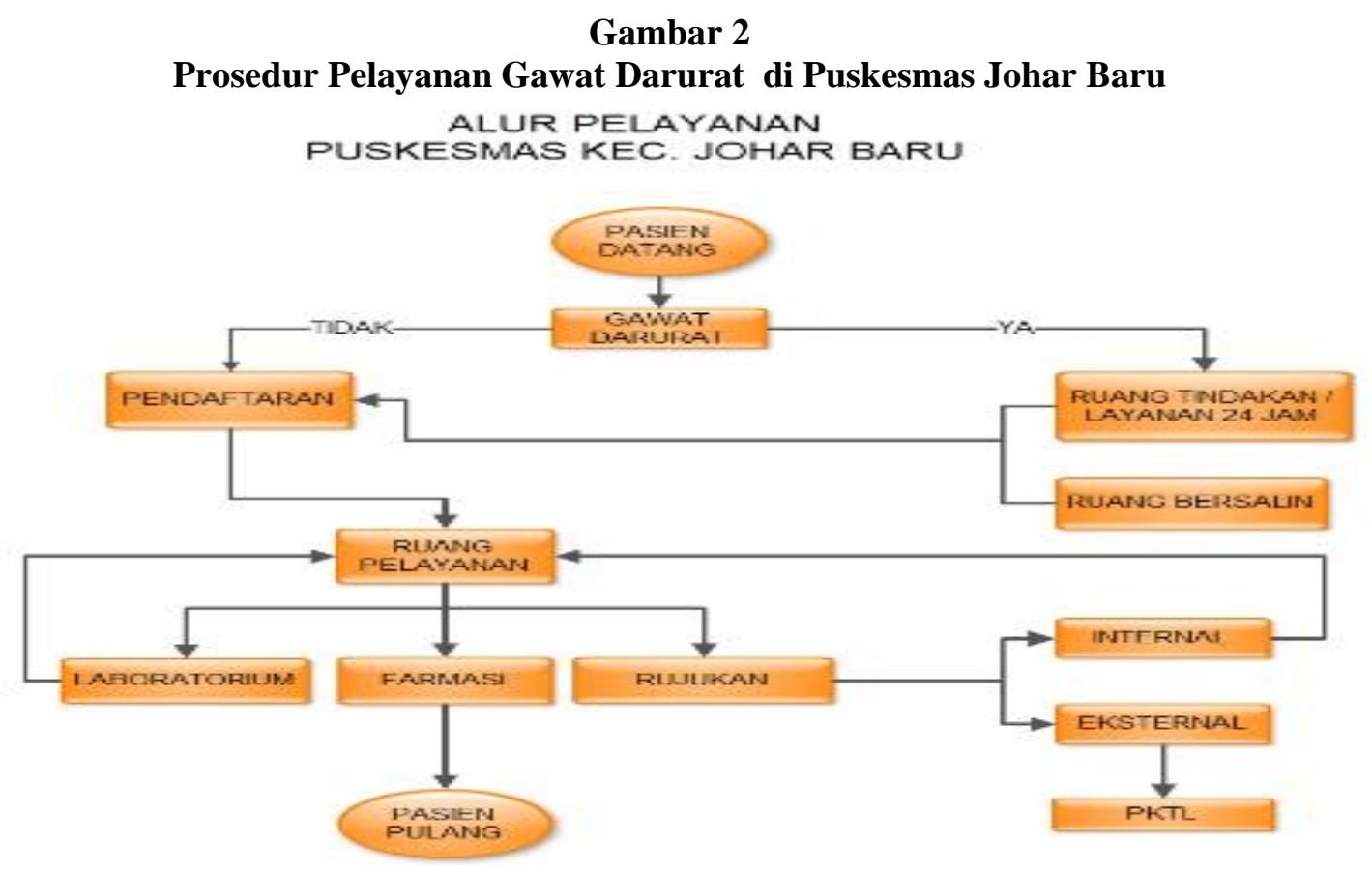

\section{METODE PENELITIAN}

Metode penelitian merupakan prosedur dan cara melakukan pengujian data yang diperlukan untuk memecahkan dan menjawab masalah penelitian. Peran metode penelitian sangat menentukan dalam menghimpun data yang diperlukan dalam penelitian dengan tujuan dan kegunaan tertentu. Menurut Sugiyono (2014:2) "Metode penelitian diartikan sebagai cara ilmiah untuk mendapatkan data dengan tujuan dan kegunaan tertentu".

\section{A. Tipe Penelitian}

Sesuai dengan permasalahan yang diteliti, yaitu mengenai, studi komparasi kepuasan pasien BPJS dan Non BPJS pada Mutu Pelayanan Pendaftaran pada Puskesmas Johar Baru, Jakarta Pusat maka tipe penelitian/metode penelitian yang sesuai adalah metode deskriptif dengan pendekatan kuantitatif dan analisis komparatif yang ditunjang oleh studi kepustakaan. menurut Sukmadinata (2013:72) mengemukakan bahwa :

Penelitian deskriptif adalah suatu bentuk penelitian yang ditujukan untuk mendeskripsikan fenomena-fenomena yang ada, baik fenomena alamiah maupun fenomena buatan manusia. Fenomena itu bisa berupa bentuk aktivitas, karakteristik, perubahan, hubungan, kesamaan, dan perbedaan antara fenomena yang satu dengan fenomena lainnya.

Adapun teknik pelaksanaan metode deskriptif pada penelitian ini menggunakan analisis komparatif yakni "pendekatan yang bertujuan untuk mengetahui perbandingan dua atau lebih karakteristik dari dua atau lebih situasi, kejadian, kegiatan, program yang sejenis atau hampir sama. "Syaodih, (2013:79).

Dalam penelitian ini pada tahap pengumpulan dan analisis data menggunakan pendekatan kuantitatif, yaitu metode pemecahan masalah berdasarkan pengumpulan data secara terencana dan sistematis, yang memungkinkan dilakukannya pencatatan data dan penganalisaan data hasil penelitian dengan perhitungan statistik dalam pembuktian hipotesis secara empiris. Sugiyono (2013:14) mengemukakan bahwa :

Metode penelitian kuantitatif dapat diartikan sebagai metode penelitian yang berdasarkan pada filsafat positivisme, digunakan untuk meneliti pada populasi atau sampel tertentu, teknik pengambilan sampel pada umumnya dilakukan secara random, pengumpulan data menggunakan instrumen penelitian, analisis data bersifat kuantitatif/statistik dengan tujuan untuk menguji hipotesis yang telah ditetapkan. 
Desain penelitian yang digunakan berdasarkan waktunya menggunakan desain cross sectional, karena variabel dependen dan independen pada subyek penelitian diukur pada saat yang sama. Notoatmodjo (2010:11)

\section{B. Definisi Konsepsional}

Untuk menghindari terjadinya kesalahan dalam menafsirkan pemahaman istilah-istilah yang akan diteliti maka peneliti menyusun definisi konseptual. Definisi konseptual merupakan batasan terhadap variabel yang dijadikan pedoman dalam penelitian, sehingga tujuan dan arahnya tidak menyimpang. penelitian memberikan definisi konseptual penelitian agar mempermudah penelitian ini dilakukan terkait masalah yang diteliti. Definisi konseptual dalam penellitian ini adalah sebagai berikut:

\section{Studi Komparasi}

Studi komparasi adalah pendekatan yang bertujuan untuk mengetahui perbedaan dua atau lebih karakteristik dari dua atau lebih situasi, kejadian, kegiatan, program yang sejenis atau hampir sama.

Studi komparatif dalam penelitian ini yaitu merupakan suatu penelitian yang berusaha untuk menemukan perbedaan antara kepuasan pasien BPJS dan Non BPJS pada Mutu Pelayanan Pendaftaran pada Puskesmas Johar Baru, Jakarta Pusat.

\section{Kepuasan Pasien}

Kepuasan adalah respon atau tanggapan pasien mengenai pemenuhan kebutuhan dan sejauh mana anggapan kinerja sesuatu memenuhi harapan pasien. Pengertian kepuasan pasien adalah perasaan senang atau kecewa seseorang yang muncul setelah membandingkan antara persepsi atau kesannya terhadap kinerja atau hasil sebuah produk dan harapan- harapannya. Selain itu kepuasan pasien adalah tanggapan pasien terhadap kesesuaian tingkat kepentingan atau harapan pasien sebelum menerima jasa pelayanan dengan sesudah menerima jasa layanan.

Kepuasan pasien dalam penelitian ini adalah kondisi yang mana masyarakat/pasien merasa senang/puas terhadap pelayanan pendaftaran pada Puskesmas Johar Baru, Jakarta Pusat.

\section{Pasien BPJS dan Non BPJS}

Pasien BPJS adalah pasien yang terdaftar sebagai peserta BPJS Kesehatan mandiri yang membiayai rawat jalan berdasarkan kepesertaan BPJS Kesehatan mandiri/Non PBI (Penerima Bantuan Iuran)

Pasien Non BPJS adalah pasien yang tidak terdaftar sebagai peserta BPJS Kesehatan yang membiayai biaya rawat jalan sendiri.

\section{Mutu/Kualitas Pelayanan Pendaftaran Rawat Jalan}

Kualitas adalah tingkat baik buruknya atau taraf/derajat sesuatu. Kualitas pelayanan disini adalah sebuah prestasi atau pencapaian dalam pelayanan kesehatan. Kualitas pelayanan juga merupakan kondisi dinamis yang berhubungan dengan produksi, jasa, manusia, proses, dan lingkungan dimana penilaian kualitasnya ditentukan pada saat terjadinya pelayanan tersebut. Peneliti menggunakan 5 dimensi (ukuran) kualitas jasa/pelayanan menurut Parasuraman, yaitu Tangible (nyata/berwujud), Emphaty (empati), Responsiveness (cepat dan tanggap), Realibility (keandalan), Assurance (kepastian).

Mutu/kualitas pelayanan dalam penelitian ini adalah kondisi yang berubah-ubah terkait dengan jasa, manusia, proses, dan lingkungan yang mana penilaian kualitasnya ditentukan pada saat terjadinya pelayanan tersebut dalam hal ini 5 dimensi/ukuran yaitu Tangible (nyata/berwujud), Emphaty (empati), Responsiveness (cepat dan tanggap), Realibility (keandalan), Assurance (kepastian) yang diberikan oleh Petugas Pelayanan Pendaftaran Rawat Jalan

\section{Pendaftaran Rawat Jalan}

Pelayanan rawat jalan merupakan pelayanan kesehatan yang diberikan kepada pasien, baik yang datang atas permintaan sendiri, maupun yang datang tanpa tinggal di ruang rawat inap Puskesmas. Baik oleh pasien yang memiliki BPJS atau tidak memiliki BPJS. Dalam hal ini 
Puskesmas Johar Baru merupakan puskesmas 24 Jam. Untuk pelayanan hanya dikhususkan pada Rawat Jalan.

\section{Variabel Penelitian}

Variabel merupakan tentang apa saja hal yang diteliti. Suryabrata (2015:24) Variabel adalah segala sesuatu yang akan menjadi objek pengamatan penelitian. Menurut fungsinya variable dibagi menjadi variabel bebas dan bebas dan variable terikat. Menurut Sugiyono (2005:39-40),

Variabel bebas/variable independen adalah merupakan variabel yang mempengaruhi atau yang menjadi sebab perubahannya atau timbulnya variabel terikat/variabel dependen. Variabel terikat/variable dependen adalah variable yang dipengaruhi atau yang menjadi akibat, karena adanya variabel bebas.

Variabel bebas pada penelitian ini adalah status pasien yang dibagi menjadi pasien BPJS dan Non BPJS yang mendaftar di rawat jalan. Variabel terikat pada penelitian ini adalah mutu pelayanan pendaftaran yang dinilai dari aspek tangible, reliability, responsiveness, assurance, dan empathy.

\section{Lokasi Penelitian}

Penelitian yang berjudul Studi Komparasi Kepuasan Pasien BPJS dan Non BPJS pada Mutu Pelayanan Pendaftaran Rawat Jalan Puskesmas Johar Baru Jakarta Pusat ini dilakukan di bagian pendaftaran di Puskesmas Johar Baru Jakarta Pusat yang terletak di Jalan Mardani Raya No. 36, Kelurahan Johar Baru, Kecamatan Johar Baru, Jakarta Pusat. Lokasi ini dipilih karena penelitian ini berfokus pada asas kebermanfaatan di masyarakat sekitar kampus IISM Stiami yang berada di Kelurahan Johar Baru, Kecamatan Johar Baru. Berdasarkan wawancara kami dengan Informan Ibu Hana Agnes Kepala Loket Lantai I Pada tanggal 5 Desember 2019 bahwa tahun 2017 sejumlah pasien 105,231 menggunakan BPJS PBI sebesar 28.368 dengan demikian total pengguna BPJS sebesar 133.599 dan yang Non BPJS data menyusul sedang proses update. Sedang pada tahun 2018 dengan rincian sebesar 106.227 pengguna BPJS PBI dan 28.081 pengguna BPJS NON PBI dengan demikan total pengguna BPJS 134,308 dan yang Non BPJS data menyusul sedang proses update.

\section{E. Jenis Data}

Sumber data utama pada penelitian kualitatif yaitu berupa kata-kata dan tindakan, selebihnya adalah data tambahan seperti data tertulis. Sumber data dalam penelitian adalah subjek darimana data dapat diperoleh Arikunto (2006:129). Data penelitian dikumpulkan sesuai dengan rancangan penelitian yang telah dilakukan. Data tersebut diperoleh dengan jalan percobaan atau pengukuran gejala yang diteliti. Data yang dikumpulkan merupakan pernyataan fakta mengenai obyek yang diteliti Kurniawan (2012:31) Berikut beberapa sumber data dalam penelitian kuatitatif, yaitu :

Dalam penelitian ini, sumber data yang digunakan yaitu :

\section{Data Primer}

Data primer adalah data yang diperoleh langsung dari subjek penelitian dengan alat pengukuran atau alat pengambil data, langsung pada subyek sebagai sumber informasi yang dicari Saryono dan Anggraeni (2013:178). Dalam penelitian ini data primer diperoleh dari kuesioner atau penyebaran daftar pertanyaan dengan responden yaitu pasien BPJS dan Non BPJS yang mendaftar rawat jalan pada Puskesmas Johar Baru, Jakarta Pusat untuk mendapatkan data tentang kepuasan responden dan mutu pelayanan pendaftaran. Kuesioner berisi pertanyaan-pertanyaan yang sudah terdapat pilihan atau alternatif jawaban.

\section{Data Sekunder}

Data sekunder adalah data yang didapatkan dari sumber lain Bustami (2011:73). Menurut Saryono dan Anggraeni (2013:178), data sekunder adalah data yang diperoleh lewat pihak lain, tidak langsung diperoleh oleh peneliti dari subjek penelitian. Data yang diperoleh dari Puskesmas Johar Baru, Jakarta Pusat berupa jumlah pasien BPJS dan Non BPJS yang mendaftar rawat jalan, dan data geografis wilayah kerja Puskesmas Johar Baru, Jakarta Pusat. 


\section{F. Populasi dan Sampel}

\section{Populasi}

Menurut Sugiyono (2016 : 80) Populasi adalah wilayah generalisasi yang terdiri atas obyek atau subyek yang mempunyai kualitas atau karakteristik tertentu yang ditetapkan oleh peneliti untuk dipelajari dan kemudian ditarik kesimpulannya. Ditinjau dari banyaknya anggota populasi, maka populasi terdiri atas :

a) Populasi terbatas (terhingga)

b) Populasi tak terbatas (tak terhingga)

Dalam penelitian ini, populasinya adalah pasien peserta BPJS dan Non BPJS yang mendaftar di Pendaftaran Pelayanan Rawat Jalan pada bulan Desember 2019, untuk populasi dalam penelitian ini adalah sebanyak 600 pasien. . Cara pemilihan sampel digunakan dengan Probability Sampling: Teknik pengambilan sampel yang memberikan peluang yang sama bagi setiap unsur (anggota) populasi untuk dipilih menjadi anggota sampel. Sugiyono (2005:92) sedangkan untuk mengambil sampel menggunakan teknik Proportionate Stratified Random Sampling : teknik ini digunakan bila populasi mempunyai anggota/unsur yang tidak homogen dan berstrata secara proporsional. Dalam penelitian ini sampel uji coba sebanyak 60 pasien. Data kuesioner diambil 2 tahap, tahap pertama Ujicoba, tahap kedua Keseluruhan. Sugiyono (2005:93). Alat yang digunakan untuk penelitian dengan Kuesioner/Angket: teknik pengumpulan data dengan menyerahkan atau mengirimkan daftar pertanyaan untuk diisi responden, Kartiwa (2015:116). Skala pengukuran yang digunakan adalah dengan skala Likert: skala yang digunakan untuk mengukur sikap, pendapat, persepsi seseorang atau sekelompok orang tentang fenomena social, Kartiwa (2015:131), Untuk besar ukuran sampel yang digunakan dalam penelitian ini Arikunto (2002:112) bahwa "untuk sekedar ancer-ancer maka apabila subjeknya kurang dari 100, lebih baik diambil semua sehingga penelitiannya merupakan penelitian populasi. Selanjutnya, jika jumlah subjeknya besar dapat diambil antara $10-15 \%$ atau 20-25\% atau lebih". Jumlah populasi pada penelitian ini adalah sebanyak 600 pasien,sampel 60 pasien.

\section{Teknik Sampling}

Teknik sampling yang digunakan dalam penelitian ini adalah Probability Sampling: teknik pengambilan sampel yang memberikan peluang yang sana bagu setuap unsur (anggota) populasi untuk dipilih menjadi anggota sampel. Jenis Probability sampling diantaranya teknik proportionate random sampling yang digunakan bila populasi mempunyai anggota/unsur yang tidak homogeny dan berstrata secara proporsional. Sugiyono (2005:93)

\section{G. Teknik Pengumpulan Data}

Teknik pengumpulan data yang digunakan dalam penelitian ini adalah kuesioner. Pengertian metode angket atau kuesioner menurut Arikunto (2002: 200), angket atau kuesioner adalah pernyataan tertulis yang digunakan untuk memperoleh informasi dari responden dalam arti laporan tentang pribadi atau hal-hal yang ia ketahui. Sedangkan menurut Sugiyono (2012: 142), angket atau kuesioner merupakan teknik pengumpulan data yang dilakukan dengan cara memberi seperangkat pertanyaan atau pernyataan tertulis kepada responden untuk dijawab. Angket berupa daftar pertanyaan atau angket tertulis. Sampel yang sesuai dengan karakteristik diberi kuesioner mengenai masalah penelitian. Kuesioner yang dipergunakan adalah kuisioner tertutup yaitu daftar pertanyaan yang disertai alternatif jawaban yang diberikan kepada 30 sampel warga mengenai Kepuasan Pasien BPJS dan Non BPJS di Puskesmas Johar Baru Jakarta Pusat.

Skala pengukuran yang digunakan dalam penelitian ini adalah Skala Likert. Sugiyono (2005:107) berpendapat bahwa:

Skala Likert digunakan untuk mengukur sikap, pendapat, dan persepsi seseorang atau sekelompok orang tentang fenomena sosial. Dengan menggunakan Skala Likert maka variabel yang akan diukur dijabarkan menjadi indikator variable, Kemudian indikator tersebut dijadikan titik tolak untuk menyusun item-item instrument yang dapat berupa pertanyaan atau pernyataan. 
Jawaban skala likert mempunyai gradasi dari sangat positif sampai dengan sangat negatif, yang dapat berupa kata-kata: Sangat setuju, Setuju, Ragu-ragu, Tidak setuju, Sangat tidak setuju.

\section{H. Teknik Pengolahan data}

Tahapan pengolahan data dalam penelitian ini meliputi kegiatan-kegiatan sebagai berikut:

\section{Editing}

Tahap editing adalah tahap yang digunakan untuk meneliti kembali data yang telah diperoleh dilapangan apakah masih terdapat kesalahan di dalam melakukan kesalahan dalam pengisiannya, tidak tepat atau terdapat keterangan fiktif.

\section{Koding}

Tahap koding adalah tahap yang mana jawaban dari responden yaitu pasien peserta BPJS dan Non BPJS yang terdaftar di rawat jalan di Puskesmas Johar Baru Jakarta Pusat, yang mana jawaban tersebut diklasifikasikan menurut jenis pertanyaan dengan memberikan nomor pada setiap kuisioner yang dimaksudkan untuk memudahkan penulis dalam mengolah data pada proses selanjutnya.

\section{Tabulating}

Tahap tabulasi adalah tahap mengelompokkan jawaban-jawaban yang serupa secara teratur dan sistematis. Tahap ini dilakukan dengan mengelompokkan jawaban-jawaban yang serupa. Melalui tabulasi data akan tampak ringkas dan bersifat merangkum. Pada penelitian ini data- data yang telah diperoleh dari lapangan kemudian disusun kedalam bentuk tabel, sehingga pembaca dapat melihat dan memahaminya dengan mudah.

\section{Interpretasi}

Tahap interpretasi adalah tahap memberikan penafsiran atau penjabaran atas hasil penelitian untuk dicari makna yang lebih luas dengan menghubungkan jawaban yang diperoleh oleh data lain agar lebih mudah dilakukan penarikan kesimpulan

\section{Teknik Analisis Data}

Analisis data menggunakan metode analisis data:

\section{Uji Validitas}

Suryabrata (2015:60) Instrumen Validitas atau tingkat ketepatan, sejauh mana instrument merekam/mengukur apa yang dimaksudkan untuk direkam/diukur. Validitas menunjukan sejauh mana skor/nilai ukuran yang diperoleh benar-benar menyatakan hasil pengukuran/pengamatan yang ingin diukur. Ukuran validitas yang digunakan adalah dengan korelasi Product Moment yang memperoleh hasil bahwa keseluruhan item pertanyaan adalah valid, dengan bantuan software SPSS For Windows, version 25.

Pertimbangan keputusan didasarkan pada $\mathrm{r}$ table untuk $\mathrm{N}=30$ pada signifikansi $5 \%$, sebesar 0.361, dapat dengan berbagai cara:

a. Perbandingan $r$ hitung denga $r$ table.

1) Jika $r$ hitung $>r$ table, maka item soal kuesioner tersebut valid.

2) Jika $r$ hitung < r table, maka item soal kuesioner tersebut tidak valid

b. Perbandingan nilai Sig. (2 tailed) dengan probabilitas 0,05

1) Jika dan nilai Sig. (2 tailed) $<0,05$ Pearson Correlation bernilai positif, maka item soal kuesioner tersebut valid

2) Jika dan nilai Sig. (2 tailed) $<0,05$ Pearson Correlation bernilai negatif, maka item soal kuesioner tersebut tidak valid

3) Jika dan nilai Sig. (2 tailed) $>0,05$ Pearson Correlation bernilai negatif, maka item soal kuesioner tersebut tidak valid 


\section{Uji Reliabilitas}

Reliabilitas instrumen Suryabrata (2015:58) menunjukan sejauh mana suatu hasil pengukuran relatif konsisten apabila alat ukur kita berulang kali. Suatu instrumen adalah reliabel sebagai alat pengumpul data apabila memberikan hasil ukuran yang sama terhadap suatu gejala pada waktu yang berlainan, dengan bantuan software SPSS For Windows 25 version.

Pertimbangan keputusan dalam Uji Reliabilitas Cronbach's Alfa:

a. Jika nilai Cronbach's Alfa $>0,60$, maka kuesioner dinyatakan reliable atau konsisten

b. Jika nilai Cronbach's Alfa $<0,60$, maka kuesioner dinyatakan tidak reliable atau tidak konsisten

\section{Analisis Data Deskriptif}

Analisis ini digunakan untuk menggambarkan tentang ringkasan data-data penelitian seperti mean. Tujuan Analisis Data Deskriptif adalah untuk membuat pencandraan secara sistemati, factual, dan akurat mengenai fkta-fakta dan sifat-sifat populasi atau daerah tertentu. Suryabrata (2015:75)

\section{Uji Beda Mann-Whitney U}

Untuk pembuktian hipotesis dilakukan dengan Uji Mann-Whitney $U$. Alasan peneliti menggunakan Uji Mann-Whitney dalam menganalisa data adalah karena pada prinsipnya adalah suatu teknik statistik untuk menguji hipotesis tentang ada tidaknya perbedaan yang signifikan antara dua kelompok sampel tanpa asumsi normalitas dan homogenitas varians. Pramesti (2018:174). Uji Mann-Whitney ini dilakukan dengan alat bantu software SPSS For Windows, version 25 .

Dasar pertimbangan pengambilan keputusan Uji Mann-Whitney U:

a. Jika nilai signifikansi atau Symp. Sig, $(2$ tailed $)<$ dari probabilitas 0,05 maka hipotesis "Ha diterima" atau ada perbedaan.

b. Jika nilai signifikansi atau Symp. Sig, $(2$ tailed $)>$ dari probabilitas 0,05 maka hipotesis "Ha ditolak" atau tidak ada perbedaan.

\section{PEMBAHASAN}

Penelitian ini bertujuan untuk mengetahui apakah ada perbedaan kepuasan pasien BPJS dan Non BPJS pada kualitas pelayanan pendaftaran rawat jalan dilihat dari 5 dimensi yaitu Tangible (Berwujud), Reliability (Keandalan), Responsiveness (Daya Tanggap), Assurance (Jaminan), dan Empathy (Empati). Berikut ini implikasi manajerial dari penelitian ini:

Berdasarkan Uji Validitas, untuk butir Item Kuesioner, pertimbangan keputusan didasarkan pada $\mathrm{r}$ table untuk $\mathrm{N}=30$ pada signifikansi $5 \%$, sebesar 0.361 , hasil keputusan nilai $\mathrm{r}$ hitung sebagai berikut:

Berdasarkan Uji Reliabilitas, untuk butir Item Kuesioner, pertimbangan keputusan didasarkan pada nilai Cronbach's Alfa $>0,60$, kuesioner dinyatakan reliable atau konsisten. Dalam penelitian ini nilai Cronbach's Alfa sebesar 0,699 dibulatkan menjadi 0,70, maka nilai Cronbach's Alfa 0,70 > 0,60, kuesioner dinyatakan reliable atau konsisten.

Berdasarkan uji hipotesis dengan menggunakan Independent Uji Mann-Whitney $U$ diperoleh nilai signifikansi atau Symp. Sig, (2 tailed) sebesar 0.001. Oleh karena nilai Symp. Sig, (2 tailed) sebesar 0.001 > dari probabilitas 0,05 maka hipotesis "Ha diterima" atau ada perbedaan.

Berdasarkan nilai rata-rata pada tingkat kepuasan pasien BPJS diperoleh rerata sebesar 79,96 untuk pasien Non BPJS diperoleh rerata sebesar 76,13 sedangkan dengan selisih keduanya sebesar 3,83

Dalam penelitian ini dapat disimpulkan bahwa tingkat kepuasan pasien BPJS lebih baik dibandingkan dengan tingkat kepuasan pasien BPJS. Pengisian kuesioner dan wawancara dengan teori empat landasan dalam mengukur tingkat kepuasan pasien bisa dijelaskan bahwa masih terdapat beberapa macam pelayanan yang belum memuaskan yaitu:

1. Harapannya Puskesmas Johar Baru tetap dapat mempertahankan dan meningkatkan mutu dan kualitas pelayanan kepada pasien yang dirasakan sudah baik. 
2. Pada hari tertentu saat padat pasien, pasien merasa menunggu terlalu lama di antrian dokter spesialis.

3. Terkait dengan aspek tangible dalam pelayanan, fasilitas parkir dan bangku ruang tunggu yang masih terasa kurang.

4. Diharapkan Puskesmas Johar Baru berupaya untuk meningkatkan kemampuan petugas kesehatan terutama di Bagian Pendaftaran dalam hal pemberian pelayanan.

\section{SIMPULAN}

Hasil penelitian ini, bisa disimpulkan bahwa ada perbedaan yang signifikan dengan tingkat kepuasan pasien BPJS dengan Non BPJS di Puskesmas Johar Baru Jakarta Pusat, dengan hasil tingkat kepuasan pasien Non BPJS lebih baik dibandingkan dengan pasien BPJS dengan selisih rerata keduanya sebesar $\mathbf{3 , 8 3}$.

\section{DAFTAR PUSTAKA}

Al-Assaf, AF, 2009, Mutu Pelayanan Kesehatan : Perspektif Internasional, Kedokteran EGC, Jakarta.

Alamsyah, Dedj.2011. Manajemen pelayanan Kesehatan. Jogjakarta. Nuha medika

Arikunto, Suharsimi. (2002). Prosedur Penelitian: Suatu Pendekatan Praktek. Jakarta: Rineka Cipta.

Azrul, Azwar. 2010. Pengantar Administrasi Kesehatan. Jakarta :Binapura Aksara.

Bustami. 2011. Penjamin Mutu Pelayanan Kesehatan dan Akseptabilitasnya. Jakarta: Erlangga.

Hardiyansyah. 2011. Kualitas Pelayanan Publik. Yogyakarta : Gava Medi8

Herlambang, S., 2016.Manajemen Pelayanan Kesehatan Rumah Sakit. Yogyakarta: Gosyen Publishing.

Ismanto Setyabudi, Daryanto. 2014, Konsumen dan Pelayanan Prima.Yogyakarta: Gava Media.

Kartiwa, Asep. 2015, Metode Penelitian Administrasi. Bandung: Pustaka Setia.

Kurniawan, Agung. 2005. Transformasi Pelayanan Publik. Yogyakarta : Pembaruan.

Kotler, Philip and Kevin Lane Keller. 2016. Marketing Management 15. PearsonEducation, Inc.

Lupiyoadi, Rambat. 2013. Manajemen Pemasaran Jasa, Edisi Ketiga.Jakarta. Salemba Empat

Madubun, Jusuf. 2017. “ Disentralisasi Pelayanan Publik di Kota Tual “. Desertasi. Makassar : Universitas Negeri Makassar.

Mahmudi. 2010. Manajemen Kinerja Sektor Publik. Edisi Kedua. Yogyakarta. UPP STIM YKPN. Yogyakarta1

Margaretha, 2003. Kualitas Pelayanan: Teori dan Aplikasi. Penerbit Mandar Maju, Bandung.

Marjati, dkk, 2014, Mutu Pelayanan Kesehatan dan Kebidanan, Salemba Medika, Jakarta.

Mubarak, Wahit Iqbal dan Nurul Chayatin. 2009. Ilmu Kesehatan Masyarakat : Teori dan Aplikasi. Jakarta : Salemba

Mukti, Ali Ghufron. 2007. StrategiTerkini Peningkatan Mutu Pelayanan Kesehatan : Konsep Implementasi. Yogyakarta : PT. Karya Husada Mukti.

Murianty, Telly.2016. “Motivasi Pelayanan Kesehatan (Studi Kasus Pada Rumah Sakit Umum Daerah Raya Kota Makassar dan Rumah Sakit Stella Maris Makassar)”. Desertasi. Makassar : Universitas Hasanuddin.

Notoatmodjo S. Metodologi Penelitian Kesehatan. Jakarta : Rineka Cipta; 201 Pasolong, Herbany. 2010. Teori Administrasi Publik. Bandung: Alfabeta

Prasetijo, R, 2005, Prilaku Konsumen, Andy offset, Yogyakarta.

Pohan, Imbalo S. 2006. Jaminan Mutu Pelayanan Kesehatan, Dasar-dasar Pengertian. Jakarta : Kesaint Blanc.

Rahmayanty, Nina. 2010. Manajemen Pelayanan Prima. Yogyakarta: Graha Ilmu.

Sabarguna, B.S., A. (2008). Sistem Informasi Klinis. Jakarta: UI Press.

Maya Sofiana (Studi Komparasi Kepuasan Pasien BPJS Dan Non BPJS Pada Mutu Pelayanan ...) 
Saputra, T., dan Herianto, M. Komitmen Organsiasi, Keadilan Organisasi, Dan Kualitas Pelayanan. Jurnal Administrasi Pembangunan, 2(2), 127-134., 2014

Saputra, T., Kepuasan Masyarakat terhadap Penyelenggaraan Kepuasan pasien (Studi Kantor Kecamatan Tambang Kabupaten Kampar, 4(2), 89-100

Saputra, T.dan Utami, Bunga, Chintia. Pelatihan Pelayanan Prima tentang Perilaku Pemberi Layanan di Rumah sakit Sidomulyo Barat Kecaman Tampan Kota Pekanbaru.1(2), 62-63., 2017.

Saryono dan Mekar Dwi Anggraeni. 2013. Metodologi Penelitian Kuantitatif dan Kualitatif dalam Bidang Kesehatan. Yogyakarta : Nuha Medika

Sukmadinata, Nana Syaodih. (2013). Metode Penelitian Pendidikan. Bandung: Remaja Rosdakarya.

Sugiyono. 2005. Metode Penelitian Administrasi. Bandung: Alfabeta

Sugiyono. 2013. Metode Penelitian Pendidikan (Pendekatan Kuantitatif, Kualitati, R\&D).Bandung: Alfabeta.

Sugiyono.2019. Penelitian Kuantitatif, Kualitatif dan R\&D. Bandung: Alfabeta.

Suryabrata. 2015. Metodologi Penelitian. Jakarta: Rajawali Pers.

Tjiptono, Fandy, 2011. Service Management, Mewujudkan Pelayanan Prima. Yogyakarta: Andi Offset

Tjiptono, Fandy. 2012. Service Management Mewujudkan Layanan Prima, Edisi Kedua. Yogyakarta. Penerbit Andi

Tjiptono, F. (2016). Sevice Quality dan Satisfaction (4 ed.). Andi: Yogyakarta.

\section{Sumber lain:}

Anonymous. Undang-undang Dasar 1945. Pembukaan Undang-undang Dasar Negara Republik Indonesia Tahun 1945.

Anonymous.Undang-undang Dasar 1945 pasal $28 \mathrm{H}$ ayat (1)

Anonymous. Kepmenkes RI No. 128 Menkes/SK/II/2004

Anonymous. Undang-undang Republik Indonesia Nomor 36 Tahun 2009 Tentang Kesehatan RI, 2009

Anonymous. Depkes RI. Undang-Undang Tentang Kesehatan Nomor 36 tahun 2009. Jakarta: Depkes RI : 2009.

Anonymous. Undang-undang Nomor 24 Tahun 2011

Peraturan Menteri Kesehatan Republik Indonesia Nomor 71 Tahun 2013. Pelayanan Kesehatan pada Jaminan Kesehatan. 2013. Jakarta : Menkes RI : 2013.

Anonymous. Peraturan Menteri Kesehatan Republik Indonesia Nomor 75 Tahun 2014 Tentang Pusat Kesehatan Masyarakat Pusat Kesehatan Masyarakat

Anonymous. Peraturan Menteri Pendayagunaan Aparatur Negara dan Reformasi Birokrasi Republik Indonesia. Nomor 15 Tahun 2014, Tentang Pedoman Standar Pelayanan.

Anonymous. Peraturan Menteri Kesehatan Republik Indonesia Nomor 46 Tahun 2015 tentang Akreditasi Puskesmas, Klinik Pratama, Tempat Praktik Mandiri Dokter, dan Tempat Praktik Mandiri Dokter Gigi,

15 Desember 2019 14:50 WIB. (15 Desember 2019). Citing Internet sources URL . https://www.spss.indonesia.com>tabelstatistik 